\title{
Description of the first instar larvae of three species of Meloe with a key to the triungulins of Central European species of this genus (Coleoptera: Meloidae)
}

\author{
JOHANNES LÜCKMANN ${ }^{1}$ and SIEGMUND SCHARF ${ }^{2}$ \\ ${ }^{1}$ University Lüneburg, Institute for Ecology and Environmental Chemistry, Scharnhorststraße 1, 21335 Lüneburg, Germany; \\ e-mail: jlueckmann@t-online.de \\ ${ }^{2}$ von-Galen-Straße 2, 46399 Bocholt, Germany
}

Key words. Taxonomy, Coleoptera, Meloidae, first instar larvae, Meloe rufiventris, Meloe uralensis, Meloe scabriusculus, key

\begin{abstract}
The first instar larvae (triungulins) of Meloe (Meloegonius Reitter) rufiventris Germar, 1817, M. (Micromeloe Reitter) uralensis Pallas, 1777 and M. (Eurymeloe Reitter) scabriusculus Brandt \& Erichson, 1832 are described, which were before unknown. The systematic relationship to closely related species is discussed. A key is included which allows to identify all triungulins of the genus Meloe from Central Europe.
\end{abstract}

\section{INTRODUCTION}

In approximately the last ten years there has been the attempt to clarify the phylogenetic relationships within the family Meloidae, especially for those phoretic taxa placed in the tribe Meloini. This work, which is largely based on first instar larval morphology, is summarized in Bologna \& Pinto (2001). Di Giulio et al. (2002) stressed that due to considerable larval heterogeneity in Meloe Linnaeus, 1758, which is the dominant genus of the tribe, anatomical descriptions of taxa representing its various lineages remain important. Larval information for Meloe serves other purposes as well. In Central Europe the genus is the most dominant group within the Meloidae. Yet in the last few decades several species have become very rare in certain areas. Because of their considerable fecundity (up to 9500 eggs/batch in M. proscarabaeus for example, see Lückmann, 2001) encountering the phoretic first instar larvae on potential Hymenoptera hosts is more likely than locating adults. Thus, monitoring populations of Meloe species for conservation efforts should depend heavily on the knowledge about their larvae and larval phenology. Identification of the first instar larvae of all Meloe species in Central Europe, started by Lückmann (1999), remains the ultimate goal.

The larvae of all Meloe subgenera from Central Europe are known and a key has been presented by Di Giulio et al. (2002). Nevertheless, larvae of certain species, namely Meloe rufiventris Germar, 1817, M. uralensis Pallas, 1777 and M. scabriusculus Brandt \& Erichson, 1832 remained unknown and are described here for the first time. In addition to detailed descriptions of these species, a key to the first instar larvae of all Meloe species from Central Europe is included which updates the key of Lückmann (1999).

\section{MATERIAL AND METHODS}

The first instar larvae of M. uralensis and M. scabriusculus were obtained from eggs, laid by adult beetles held for breeding experiments. The beetles were collected between 19 and 24 April, 1998 in the surroundings of the Neusiedlersee, Austria.

Based on Selander (1986), the following rearing method was used: The adults were kept individually in a plastic terrarium $(20 \times 13 \times 13 \mathrm{~cm})$ with a slitted lid. The bottom was filled with $3 \mathrm{~cm}$ moist sand and wetted regularly. The beetles were kept under natural day-night light conditions at temperatures of $21-25^{\circ} \mathrm{C}$ during the day and $15-18^{\circ} \mathrm{C}$ at night. To guarantee a good food supply, the beetles were fed fresh cleavers (Galium aparine) every morning and evening in surplus. Plants were moistened with tap water using a laundry sprayer. Egg clutches which had been laid in burrowed cavities and in most cases next to the transparent walls of the plastic boxes were recorded and left in the sand until emergence of the triungulins to the soil surface.

One female of M. rufiventris was found laying eggs on 22 April, 1998 near the Neusiedlersee and was removed from her cavity. Her egg clutch was dug out and put into a sand filled plastic tube about $2 \mathrm{~cm}$ deep (data on the reproductive biology of the examined species and six other Meloidae from Central Europe are given in Lückmann, in prep.).

Hatched triungulins were preserved in Scheerpletz-solution (65\% alcohol and 5\% acetic acid) and deposited in the collection of J. Lückmann. Morphological analysis and measurements were carried out using a light microscope for examining larva, and a scanning electron microscope for examining material mounted on plates, prepared by critical point dehydration and gold sputtering.

The terminology of larval structures is primarily based on MacSwain (1956) and Bologna \& Pinto (2001); for description of larval chaetotaxy notational conventions used by Selander (1990), Bologna \& Di Giulio (2002) and Di Giulio et al. (2002) were adopted.

Larvae specimens of all species studied were sent to Marco A. Bologna (Rome, Italy) for his ongoing comparative investigations of Meloe subgenera. General features of these species were included in the paper of Di Giulio et al. (2002).

\section{RESULTS}

\section{Egg morphology}

Eggs of M. rufiventris, M. uralensis and M. scabriusculus are orange-yellow, rounded at both ends, and 
slightly wider at one end. The range of egg length/width for the species studied is as follows: $M$. rufiventris $1.08-1.40 \mathrm{~mm} / 0.35-0.48 \mathrm{~mm}$; M. uralensis $0.83-1.03$ $\mathrm{mm} / 0.30-0.38 \mathrm{~mm}$; and for $M$. scabriusculus $0.63-0.78$ $\mathrm{mm} / 0.23-0.30 \mathrm{~mm}$.

\section{Larval morphology of Meloe rufiventris}

Habitus. Triungulin campodeiform; body elongate, nearly parallel sided (Figs 1a, b). Body length (from labrum to pygidium) $1.20-1.70 \mathrm{~mm}$, with two pairs of caudal setae: the longer pair $0.50-0.60 \mathrm{~mm}$, the shorter one $0.13-0.14 \mathrm{~mm}$. Greatest width of head $0.32-0.33$ $\mathrm{mm}$, greatest length $0.21 \mathrm{~mm}$. Length/width of antennal segments I, II, III: $0.01 / 0.04,0.05-0.06 / 0.03,0.07-0.08$ / $0.01 \mathrm{~mm}$, respectively; terminal seta approximately 0.20 $\mathrm{mm}$ long. Ocular seta long, approximately $0.10 \mathrm{~mm}$ and posterior to each stemma. Greatest width of pronotum $0.35 \mathrm{~mm}$, meso- and metanotum as wide as pronotum; greatest length of pro-, meso and metanotum $0.22-0.25$ $\mathrm{mm}, 0.20 \mathrm{~mm}$ and $0.17 \mathrm{~mm}$, respectively. Ecdysial suture on pro- and mesothorax. Each abdominal segment with equal length of $0.1 \mathrm{~mm}$. Body colour yellow-orange.

Head. Head transverse, 1.5 times wider than long, widest at stemmata (Fig. 1c); anterior margin rounded. Stemmata laterally situated, prominent, set in the first basal third of head. Transverse ridge at base of vertex. Epicranial suture Y-shaped, with short stem (less than $1 / 10$ of head length), dividing into arms near head base just behind the stemmata; arms clearly diverging from base towards the edge of frontoclypeus and ending just behind base of antennae. Frontoclypeus not concave between arms of epicranial suture. Frontoclypeal region with 14-16 setae: frontoclypeal row (FCR) with three pairs of setae (FCR1 short, if missing then sensory pits are present, FCR2 and FCR3 moderately long); sensory pit between FCR2 and FCR3; two pairs of setae along arms of epicranial suture; sensory pit near first pair; frons with 2-3 pairs of additional setae laterally. Two pairs of setae (one moderately long and one short) to either side of epicranial stem. One sensory pit and one long ocular seta posterior to each stemma. Antennal segment I (Fig. 1e) very short, transverse and approximately twice as wide as long; segment II approximately 1.8 times longer than wide, asymmetrical, sensory appendix not visible; segment III slender, approximately seven times longer than wide and as long as segment I and II together or slightly longer; terminal seta approximately 1.3 times longer than entire antenna. Labrum (Fig. 1d) narrow, transverse, with rounded sides, not visible dorsally and distinctly separated from frontoclypeus; with 19-20 short setae: 17-18 along the edge and two in middle of labrum. Maxillary and labial palpi elongate, cylindrical. Segment III of maxillary palpi slightly obliquely truncate, with eleven short, evenly distributed sensilla and one longer sensillum laterally at apex; length twice that of segment I and II together. Maxilla with simple mala. Segment III of labial palpi rounded at apex, with eight short, evenly distributed sensilla and one longer sensillum laterally. Mandible with broad base, narrowed in dagger-like fashion; inner side gently curved, outer side angulate in apical half; inner and outer surfaces smooth; each mandibular base with two short setae.

Thorax. Pronotum subrectangular, nearly as broad as head, narrowing towards apex; 1.4-1.5 times wider than long. Meso- and metanotum nearly rectangular and as wide as pronotum. Pronotum approximately 1.2 and 1.4 times longer than meso- and metanotum, respectively. Pronotum with eight setae in anterior row (AR), two lateral in middle row (LMR), two central in middle row (ZMR) and ten in posterior row (PR). Meso- and metanotum with four setae in AR, two in LMR and ten in PR, respectively. All setae subequal in length. Each thoracic sternite with two short setae in MR and PR. Trochanter with few setae; one very long seta situated ventrally near base, approximately as long as trochanter. Femora slightly swollen; basal third with one long seta, ventrally situated, and approximately as long as femur; several shorter setae adjacent to elongate seta. Tibiae slender, moderately compressed and only slightly tapered. Claw compressed, basal pair of setae narrowly spathulate and slightly longitudinally corrugated, together forming a trident-like structure (Fig. 1f).

Abdomen. Abdomen approximately as long as head and thorax together; all abdominal segments of equal length. Tergites transverse, narrow, subrectangular. Tergite I-VIII without setae in AR, two in LMR and two in ZMR, 18 setae in PR. PR8 and PR9 on tergites II-VIII distinctly longer than others; PR8 approximately 1.5 times longer than PR9 and nearly as long as its abdominal segment. Tergite IX with similar setation and with two pairs of elongate setae (caudal setae): the longer pair nearly as long as entire abdomen, the shorter pair as long as tergite IX. All abdominal sternites with two short setae in AR, no setae in MR and eight setae in posterior row. PR1 on sternite I very short and thin; PR2 also short, but always longer than PR1; PR3 strong and moderately long; PR4 thin but as long as PR3. On sternites II-VIII, PR1 becomes progressively longer until it is as long as PR2 and PR4; PR3 always distinctly longer than other setae on sternites. Pygopod membranous, transversely divided into two parts: the dorsal one V-shaped with six setae and numerous dentate chitinised plates; the ventral one longitudinally divided into two lobes.

Spiracles. All spiracles circular, positioned laterally, not projected beyond thoracic and abdominal segments (Fig. 1g). Those on mesonotum and abdominal segment I equal in size, twice the diameter of those on abdominal segments II-VIII. Marginal rings not protruding. At least spiracles on mesonotum and first abdominal segment (Fig. 1h) with a reticulate surface internally, and strengthened by a hexagonal pattern of partially elevated strips and sieve-like perforations.

Remarks. Although M. rufiventris and M. cicatricosus Leach, 1852 were attributed to the subgenus Meloegonius their larvae are quite different. A detailed description of the first instar larva of $M$. cicatricosus is given by Selander (1989). Di Giulio et al. (2002) pointed out that these differences include the unmodified shape of abdominal spiracle I (greatly enlarged, transversely oval, 

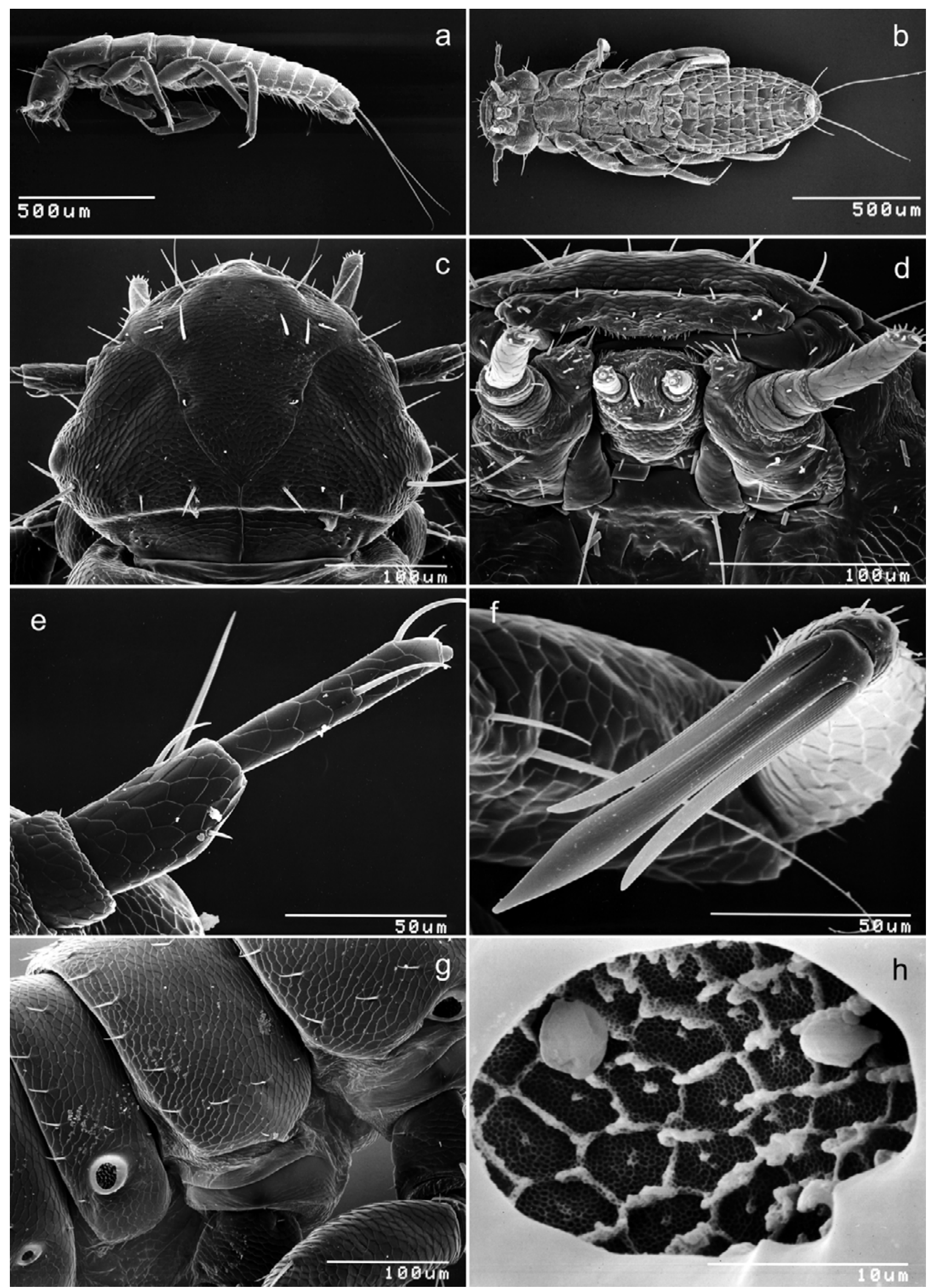

Fig. 1. Meloe rufiventris, SEM photographs of first instar larva. a - habitus in lateral; $b$ - ventral view; $c$ - head dorsal; $d-$ head ventral; e - left antenna ventral; $\mathrm{f}$ - prothoracic claw ventral; $\mathrm{g}$ - spiracles on mesothoracic, $1^{\text {st }}$ and $2^{\text {nd }}$ abdominal segment in lateral view; $\mathrm{h}$ - left spiracle on $1^{\text {st }}$ abdominal segment in lateral view. 
projecting beyond sides of abdominal segment in $\mathrm{M}$. cicatricosus), the almost obsolescent antennal sensory appendix (campaniform, not prominent in M. cicatricosus), and the considerably more poorly sclerotized abdominal sternites. Furthermore, the head setae are shorter and thicker in M. rufiventris, the setation on the thoracic and abdominal sternites is obviously different too, the transverse ridge is present (missing in M. cicatricosus), and the length ratio between antennal segments III and II is smaller than in M. cicatricosus. Since the larval differences are very distinct it is debatable whether both species belong or not to the same subgenus.

\section{Larval morphology of Meloe uralensis}

Larva similar to that of $M$. rufiventris except for the following characters.

Habitus. Body short, slightly fusiform (Figs 2a, b). Body length 1.0-1.2 mm, with two pairs of caudal setae, the longer pair $0.20 \mathrm{~mm}$, the shorter one $0.07 \mathrm{~mm}$. Greatest width of head $0.27-0.28 \mathrm{~mm}$, greatest length $0.24-0.25 \mathrm{~mm}$. Length/width of antennal segments I, II, III $0.017 / 0.034,0.017 / 0.028,0.070 / 0.008 \mathrm{~mm}$, respectively; terminal seta approximately $0.17 \mathrm{~mm}$ long. Orbital seta not distinctively longer compared to other setae. Width/length of pro-, meso- and metanotum 0.27/0.15, $0.25 / 0.11,0.25 / 0.11 \mathrm{~mm}$. Each abdominal segment with approximately same length of $0.06 \mathrm{~mm}$. Head and abdominal segments II-IX brownish with a circular dark area around stemmata and at edge of the frontoclypeus; thorax (incl. legs) and abdominal segment I light yellow.

Head. Head slightly transverse, widest near base; slightly wider than long; anterior margin straight. Stemmata set at the end of the basal half of head, onwards situated, not prominent, small. Epicranial suture with long stem (approximately $1 / 3$ of head length). Frontoclypeal region with 14 setae: frontoclypeal row with three pairs of setae (FCR1, FCR2, FCR3, all subequal in length) aligned directly at margin of frontoclypeus (Fig. 2c); sensory pit between FCR2 and FCR3; three pairs of setae along arms of epicranial suture; sensory pit between first and second pair; frons with one pair of additional seta laterally. Two moderately long pairs of setae to either side of epicranial stem. Three moderately long setae anterior to stemmata in one row and one sensory pit posterior to each stemma. Antennal segment II very short, transverse (Fig. 2e), 1.7 times wider than long; in contrast to $M$. rufiventris with conical sensory appendix, which is as wide as long and positioned on apex; segment III slender, approximately eight times longer than wide and twice the length of segment I and II together; terminal seta approximately 3.3 times longer than segment III and 2.2 times longer than entire antenna. Labrum (Fig. 2d) with ten moderately short setae: three setae at both ends, four setae in middle part. Segment III of maxillary palpi depressed at distal half, strongly obliquely truncate, with 10-20 short, evenly distributed sensilla and one or two longer sensilla at top of apex; length 2.5 times that of segment I and II together. Segment III of labial palpi rounded at apex, with 6-7 short, evenly distributed sensilla and one very long sensillum laterally. Postmentum with four setae.

Thorax. Pronotum 1.8 times wider than long; approximately 1.3 times longer than mesonotum and metanotum, respectively; with four setae in AR, two in ZMR and eight in PR. Meso- and metanotum with eight setae in $\mathrm{AR}$, four in LMR, two in ZMR and eight in PR, respectively. All setae minute and subequal in length. In contrast to $M$. rufiventris there is one long seta dorsally situated on trochanter, more than half of trochanter's length. Femora not swollen; basal third with one long ventral seta, which is nearly half as long as femur. Tibiae slender with numerous long setae. Claw conicofalcate, moderately compressed with concave cross-section in middle part, outer surface deeply corrugated longitudinally and inner surface smooth; basal pair of setae setiform, not spathulate, deeply corrugated, slightly displaced in position and of equal length (Fig. 2f); claw at hind leg approximately 0.4 times the length of tibia.

Abdomen. Abdomen slightly fusiform (Fig. 2b); maximum width at segment III. Head and thorax together approximately 1.2 times longer than abdomen; all abdominal segments subequal in length (Fig. 2a). Tergite segment I without setae in AR, 3-4 in MR and ten in PR. Segments II-VIII without setae in AR, six in MR and twelve in PR; all setae on tergites very short except PR5 on segments II-VIII which are nearly half the tergites length. Tergite IX with two pairs of caudal setae: the longer pair as long as tergites VI to half tergite IX, the shorter pair as long as tergite IX. Sternite I semioval with no setae in AR and MR and six in PR; PR1 approximately three times of PR2 and PR3; sternites II and III with two very short setae in AR, MR without setae and four longer (PR1 and PR3) and four shorter (PR 2 and PR 4) in alternating position in PR. Sternites IV-VIII with two setae in AR, two short setae in MR and four longer (PR1 and PR3) and four shorter setae (PR 2 and PR4) in alternating position; PR1 and PR3 about twice the length of PR2 and PR4. Sternite IX with six setae in PR. Pygopod similar to M. rufiventris, membranous and transversely divided into two parts, the dorsal one with crest-like, papillary stripes.

Spiracles. Mesonotum and abdominal segments II-VIII with circular, laterally placed spiracles; those from mesonotum twice the diameter compared to those on abdomen; in contrast to M. rufiventris, abdominal segment I with large transverse, dorsally placed spiracles (Fig. 2g). Marginal rings slightly protruding. At least surface of spiracles on mesonotum and abdominal segment I similar to those of M. rufventris (Fig. 2h).

Remarks. $M$. uralensis and $M$. decorus Brandt \& Erichson, 1832 belong to the subgenus Micromeloe. This relationship is reflected by the great similarity of the first instar larvae. The first instar larva of $M$. decorus was first described by Bologna \& Pinto (1995). Di Giulio et al. (2002) mentioned the presence of the ocular pit in $M$. uralensis, which is lacking in $M$. decorus and was originally treated as an apotypy of this subgenus by Bologna $\&$ Pinto (1995). A further obvious difference is the col- 

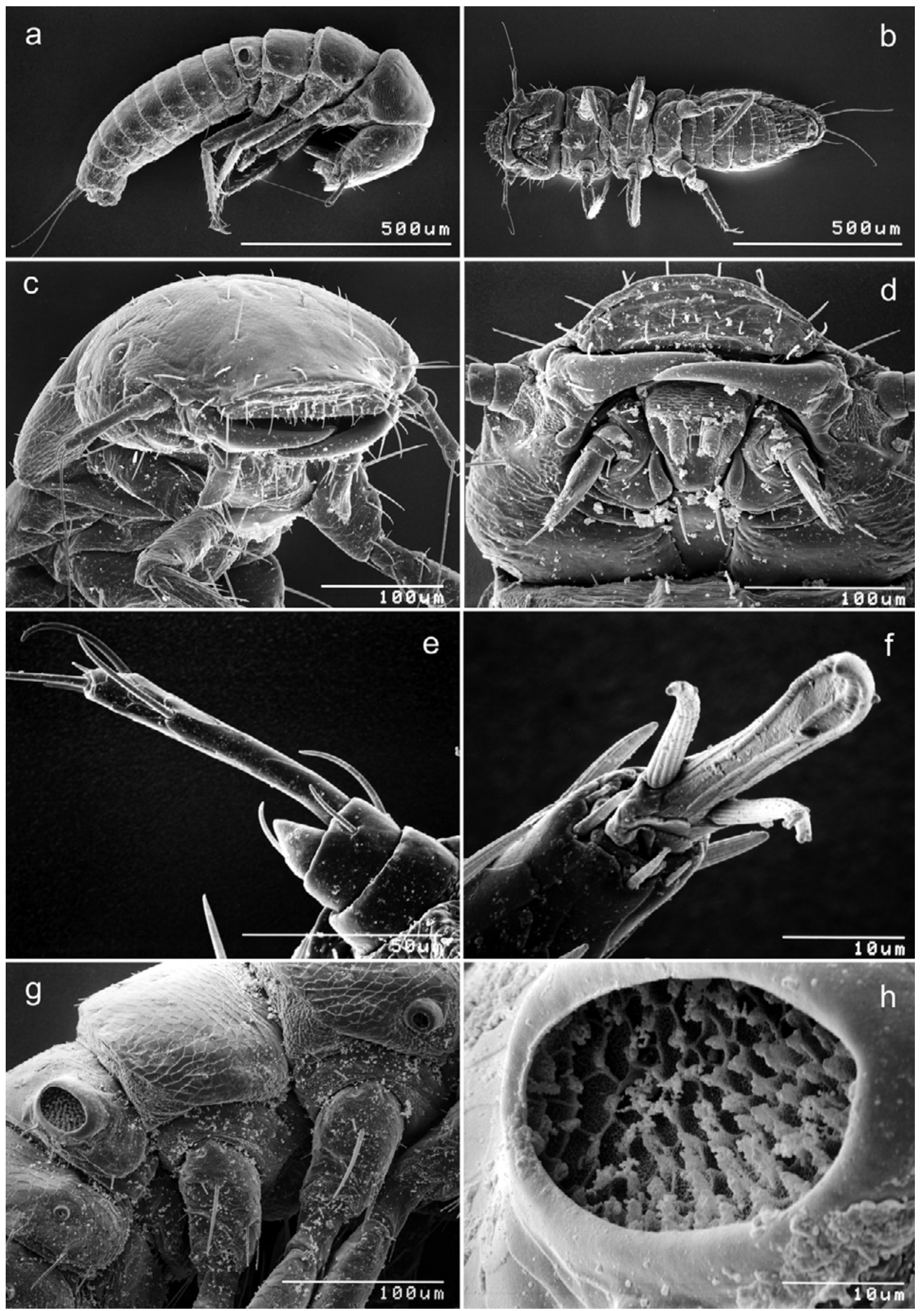

Fig. 2. Meloe uralensis, SEM photographs of first instar larva. a - habitus in lateral; b - ventral view; $\mathrm{c}-$ head dorsofrontal; $\mathrm{d}-$ head ventral; e - right antenna ventral; $\mathrm{f}$ - prothoracic claw ventral; $\mathrm{g}$ - spiracles on mesothoracic, $1^{\text {st }}$ and $2^{\text {nd }}$ abdominal segment in lateral view; $\mathrm{h}$ - right spiracle on $1^{\text {st }}$ abdominal segment in lateral view. 
oration of the first thoracic segment, which is light yellow in M. uralensis and brownish in M. decorus.

Micromeloe is closely related to the subgenus Eurymeloe (incl. Coelomeloe Reitter, 1911) because for the species of these subgenera claws are not spathulate, femora are not swollen, antennal segments II bear a subconical sensory appendix, dorsal setae are considerably shortened and the abdomen is shorter relative to the remainder of the body (Bologna \& Pinto, 1995; Di Giulio et al., 2002). Among other characters, the separation of Micromeloe from the mentioned subgenus is due to the possession of two pairs of caudal setae, claws moderately compressed and concave in cross-section, and posterior parts of abdominal sternites not microserrated.

Beside these morphological differences, Micromeloe is separated from all Meloe species by a particular behavioural element. At least $M$. decorus shows a fanning courtship behaviour (Lückmann, in press), which was before unknown for this genus and which is in some aspects similar to that of Lytta vesicatoria Fabricius, 1775. Further, larvae seem not to be phoretic since at breeding experiments in the laboratory they did not clasp to offered hymenopterans. This hypothesis is supported by observations of Vrabec et al. (2001) who never found larvae on bees collected in bee colonies where $M$. decorus had laid eggs. They discussed the possibility of direct active infiltration of the triungulins into the bee nests. This would mean that Micromeloe would be the second non-phoretic subgenus within the Meloini next to Physomeloe Reitter, 1911. The only species $P$. corallifer (Germar, 1818) was previously assigned to Meloe. The placement of Physomeloe in the Meloini is suggested by Bologna \& Pinto (2001) and summarized in Bologna \& Pinto (2002).

\section{Larval morphology of Meloe scabriusculus}

Larva similar to that of $M$. rufiventris except for the following characters.

Habitus. Body length $0.7-1.0 \mathrm{~mm}$, with one pair of $0.17 \mathrm{~mm}$ caudal setae (Figs $3 \mathrm{a}, \mathrm{b}$ ). Greatest width of head $0.18-0.19 \mathrm{~mm}$, greatest length $0.12-0.13 \mathrm{~mm}$. Length/ width of antennal segments I, II, III $0.011 / 0.022$, $0.019 / 0.017,0.050 / 0.006 \mathrm{~mm}$, respectively; terminal seta approximately $0.15 \mathrm{~mm}$ long. Width/length of pro-, meso- and metanotum 0.18/0.13, 0.18/0.08, 0.18/0.07 $\mathrm{mm}$, respectively. All abdominal segments with equal length of $0.06 \mathrm{~mm}$. Body yellow coloured except small circular, dark areas around stemmata.

Head. Head subhexagonal, transverse, widest at base before stemmata position (Fig. 3c); approximately 1.35 times wider than long. Stemmata onwards situated, not prominent, small, set at the end of basal third of head. No transverse ridge at base of vertex. Epicranial suture with short stem (approximately $1 / 5$ of head length); arms slightly diverging from base forward in first half, more or less parallel, then bending and running to margin of fron- toclypeus, ending near base of antennae. All setae on head moderately long and equal in length. Frontoclypeal region with 18 setae: frontoclypeal row with four pairs of setae (FCR1-FCR4) aligned directly at margin of frontoclypeus; no sensory pit between FCR2 and FCR3; four pairs of setae along arms of epicranial suture (sometimes a seta could be absent); no sensory pit between first and second pair; frons with one pair of additional setae laterally. One pair of setae to either side of epicranial stem base and one pair shortly after branching of epicranial suture close to arms. Six setae around each stemma but sensory pit absent. Antennal segment II (Fig. 3e) asymmetrical, subquadratic, apex oblique; sensory appendix conical, slightly wider than long; segment III slender, approximately nine times longer than wide and 1.5 times longer than segments I and II together. Terminal seta approximately three times longer than segment III and approximately two times longer than entire antenna. Labrum (Fig. 3d) with 16 setae: one short and one long seta at left and right margin, respectively; remaining setae short, distributed in middle part of labrum. Segment III of maxillary palpi depressed at posterior part, strongly obliquely truncate and with approximately twelve short, evenly distributed sensilla; one or two of them at top of apex at least twice the length of remaining sensilla. Segment III of labial palpi like in $M$. rufiventris, but with middle sensillum distinctly elongate. Mandible with inner and outer margins gently curved.

Thorax. Pronotum 1.4 times wider than long, approximately 1.6 times as long as mesonotum and approximately 1.8 longer than metanotum, respectively. Pronotum with eight setae in AR, eight in MR and ten in PR; meso- and metanotum with two setae in LAR, four in LMR, two in ZMR and ten in PR, respectively. All setae minute and subequal in length. Trochanter with three dorsal elongated setae. Femora (Fig. 3a) not swollen; basal third with one long ventral seta, which is nearly half as long as femur. Claw conicofalcate (Fig. 3f), circular in cross-section; basal pair of setae setiform, not spathulate and of equal length; claw and setae slightly corrugated, claw of hind leg approximately 0.4 times the length of tibia.

Abdomen. Abdomen approximately 1.3 times longer than head and thorax together. Tergite I with two pits or setae in ZAR, two in MR, 16 in PR; PR1-PR4 between spiracles and PR5-PR8 beside each spiracle; all setae subequal in length. Tergite II-VIII with two pits or setae in ZAR, two in ZMR and two in LMR; 16 equal-sized setae in PR with PR7 approximately three times longer than PR1-PR6 and approximately twice as long as PR8. Tergite IX with one pair of caudal setae, which are as long as tergites VII-IX together. Sternite I-VIII without setae in AR and MR and ten in PR; PR4 up to twice as long as other setae in PR; sternite IX with six setae in PR; all posterior edges of sternites microserrate. Pygopod like

Fig. 3. Meloe scabriusculus, SEM photographs of first instar larva: a - habitus in lateral; $\mathrm{b}$ - ventral view; $\mathrm{c}-$ head dorsal; $\mathrm{d}-$ head ventral; e - right antenna ventral; $\mathrm{f}$ - prothoracic claw ventral; $\mathrm{g}$ - spiracles on mesothoracic, $1^{\text {st }}$ and $2^{\text {nd }}$ abdominal segment in lateral view; $\mathrm{h}$ - right spiracle on $1^{\text {st }}$ abdominal segment in lateral view. 

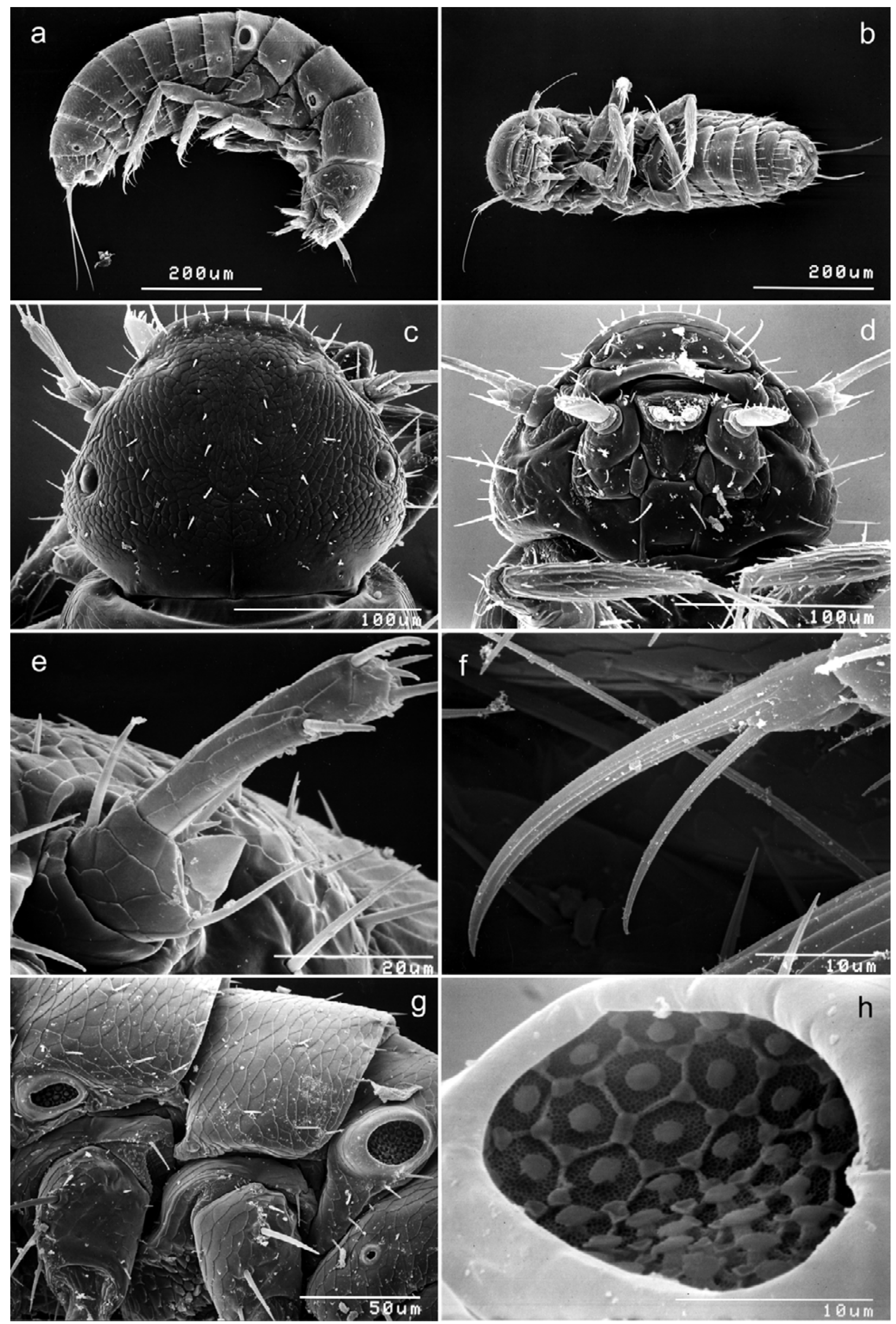
in $M$. rufiventris membranous and transversely divided into two parts, the dorsal one with crest-like, papillary stripes.

Spiracles. Mesonotum and abdominal segment I with differently sized, oval spiracles (Fig. 3g); abdominal segments II-VIII with small circular spiracles with those on segment VIII slightly larger than spiracles on segments II-VII. Spiracles on mesonotum and abdominal segments II-VIII laterally placed, with marginal rings slightly protruding. Spiracles on abdominal segment I dorsally situated, with marginal rings distinctly protruding. At least spiracles on mesonotum and first abdominal segment with a reticulated, sieve-like perforated surface internally, and strengthened by a flat hexagonal strip pattern; each corner and each cell centre papillated (Fig. 3h).

Remarks. The triungulin of M. scabriusculus is very similar to that of M. rugosus Marsham, 1802, which was first described by Lückmann \& Kuhlmann (1997).

The most obvious difference between both species is the coloration. In M. rugosus the entire head, the pronotum and sometimes also the meso- and metanotum are light brownish. Further, the parietal regions of the head are dark coloured. In contrast, the triungulin of $M$. scabriusculus is totally yellow coloured except for brownish, circular areas around the stemmata. In M. scabriusculus the head is wider than long whereas in M. rugosus it is the opposite. The frontoclypeal row in M. scabriusculus bears four pairs of short, equally long setae (FCR1-FCR4), whereas in M. rugosus there are two pairs of longer setae (FCR1 and FCR2). The frons is not concave in M. scabriusculus but it is in M. rugosus. Generally, setation on abdominal segments II-VII is distinctly shorter in M. scabriusculus: setae on the abdominal tergites reach at the most one quarter of the tergite (except PR7) and at the most half of the sternite (except PR4). In $M$. rugosus setae length is approximately half to three quarters that of the tergite (except PR5) and approximately half of the entire sternite. Caudal setae are as long as abdominal tergites VII-IX in M. scabriusculus and as long as tergites VI-IX in M. rugosus.

The triungulin of M. scabriusculus also resembles that of $M$. brevicollis. Apart from the body colour, which is dorsally brownish and ventrally yellowish in M. brevicollis, the morphological differences between them are much more obvious than between $M$. scabriusculus and $M$. rugosus. In comparison to $M$. scabriusculus, the anterior edge of the frontoclypeus of $M$. brevicollis is distinctly extended, ending semi oval, with mandibles lying on the underside of the head and the labrum having a groovelike deepening in which setae of hymenopterans are inserted (Lückmann \& Kuhlmann, 1997). The head is approximately one fourth of the body length whereas in $M$. scabriusculus it is one sixth. The abdomen of $M$. brevicollis is distinctly fusiform with spiracles on segments II-VIII lying ventrally whereas the abdomen of $M$. scabriusculus is parallel sided with spiracles laterally placed.

\section{Key to the first instar larvae of the genus Meloe from Central Europe}

In the key of Lückmann (1999) to the first instar larvae of Central European Meloe, M. decorus, M. mediterraneus G. Müller, 1925 and M. hungarus Schrank, 1776 were not included, and those of $M$. scabriusculus were not known at the time. The first instar larva of $M$. hungarus was actually described by Cros (1930) although it was not identified as such. Bologna (1994a) noted that Cros' description refers to $M$. hungarus and also related a short description of Danielyan \& Nabaldyan (1971) to this species. Its characters were summarized by Bologna \& Pinto (2001).

The present key now includes all known species from Central Europe and incorporates the more recent nomenclatural changes (Kaszab, 1981; Bologna \& Pinto, 1997). The only problem that remains to be solved are the two larval forms of M. violaceus Marsham, 1802 (Blair, 1942; van Emden, 1958).

Apart from the first instar larvae described in the first part of this paper, information related to dimensions or differentiating features of the triungulins was based on:

own material of $M$. violaceus (dark form), M. proscarabaeus Linné, 1758, M. variegatus Donovan, 1793, M. decorus, M. brevicollis Panzer, 1793 and M. rugosus Marsham, 1802;

the following papers (selection): $M$. violaceus (pale form: Newport, 1851, dark form: Weber, 1893; Blair, 1942; Cros, 1934); M. proscarabaeus (Cros, 1921, 1929a; van Emden, 1943); M. autumnalis Olivier, 1792 (Cros, 1914, 1921); M. variegatus (Assmuss, 1865; Cros, 1929a, 1941); M. tuccius Rossi, 1792 (Cros, 1919, 1929b); M. cicatricosus (Selander, 1989); M. hungarus (Cros, 1930; Danielyan \& Nabaldyan, 1971; cf. Bologna, 1994a); $M$. decorus (Bologna \& Pinto, 1995); M. brevicollis Panzer, 1793 (Cros, 1929a; Hachfeld, 1928, 1931; Bologna et al., 1989; Lückmann \& Kuhlmann, 1997); M. mediterraneus (Cros, 1921, 1935; cf. Bologna, 1988).

Scientific literature which includes relevant descriptions of larvae from Central Europe is much more numerous. For more information see Bologna (1991), Bologna (1994b), Bologna \& Pinto $(2001,2002)$ and Di Giulio et al. (2002).

1 Claw compressed; basal pair of setae narrowly spathulate, together forming a trident-like structure (Fig. 1f). Two pairs of caudal setae ..................... 2

- Claw not compressed; basal pair of setae not narrowly spathulate (Fig. 3f). One or two pairs of caudal setae ...9 9

2 Body shiny black. Head with a transverse row of flattened, lanceolate setae along anterior margin of frontoclypeus. Abdomen with long, upright standing black setae ........ $\ldots . . . \ldots . . . M$. (Lampromeloe) variegatus Donovan, 1793
Body red-brown or yellow to orange; if black then not shiny black. Head without a transverse row of flattened, lanceolate setae along anterior margin of frontoclypeus. Abdomen with or without upright setae $\ldots \ldots \ldots \ldots \ldots \ldots$

3 Body large, length approximately $4 \mathrm{~mm}$, red-brown. Head with robust, distinctly serrated mandibles. Abdomen with long, robust setae. Caudal setae nearly equally long ...... .......... M. (Listromeloe) hungarus Schrank, 1776 
- Body distinctly shorter. Body yellow to orange or black. Mandibles smooth or microserrated. Abdomen without long, robust setae. $1^{\text {st }}$ pair of caudal setae distinctly longer than $2^{\text {nd }}$

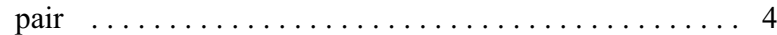

4 Body black $\ldots \ldots \ldots \ldots \ldots \ldots \ldots \ldots \ldots \ldots \ldots \ldots$

............. M. (Meloe) violaceus* Marsham, 1802

- Body yellow to orange $\ldots \ldots \ldots \ldots \ldots \ldots \ldots \ldots$

5 Body length $2.0-2.5 \mathrm{~mm} \ldots \ldots \ldots \ldots \ldots \ldots \ldots$

- Body length less than $2.0 \mathrm{~mm} \quad \ldots \ldots \ldots \ldots \ldots \ldots . \ldots$

6 Head hexagonal. Length of $3^{\text {rd }}$ antennal segment twice that of $2^{\text {nd. }} 2^{\text {nd }}$ antennal segment slightly longer than wide; terminal seta approximately three times the length of antenna

M. (Meloegonius) cicatricosus Leach, 1815

- Head regularly rounded. $3^{\text {rd }}$ antennal segment nearly as long or slightly shorter than $2^{\text {nd }}$ segment; $2^{\text {nd }}$ antennal segment nearly twice as long as wide; terminal seta nearly as long as antenna ........ M. (Meloe) violaceus* Marsham, 1802

7 Basal pair of claw setae black, claw light. $3^{\text {rd }}$ antennal segment distinctly shorter than $2^{\text {nd }}$

............ M. (Treiodous) autumnalis Olivier, 1792

- Basal pair of claw setae yellow. $3^{\text {rd }}$ antennal segment longer or only slightly shorter than $2^{\text {nd }} \ldots \ldots \ldots \ldots \ldots$

$83^{\text {rd }}$ antennal segment longer than $2^{\text {nd }}$. Ocular seta strong and much longer than adjacent setae (Fig. 1a) ............

........... M. (Meloegonius) rufiventris Germar, 1817

- $3^{\text {rd }}$ antennal segment as long as or only slightly shorter than $2^{\text {nd }}$. Ocular seta not strong, length subequal to adjacent setae

............. M. (Meloe) proscarabaeus Linné, 1758

9 Two pairs of caudal setae. Body bicoloured. Head and most segments of abdomen brown, remaining parts yellow .....

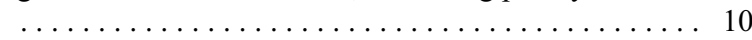

- One pair of caudal setae. Body uniformly reddish, brown or black; if yellow, head and prothorax brownish and lateral parts of head dark brown $\ldots \ldots \ldots \ldots \ldots \ldots \ldots .11$

10 Head and $2^{\text {nd }}-9^{\text {th }}$ abdominal segments brown; thorax and $1^{\text {st }}$ abdominal segment light yellow. Terminal seta approximately 2.6 times longer than $3^{\text {rd }}$ antennal segment; this segment also approximately 4 times longer than $2^{\text {nd }}$ antennal

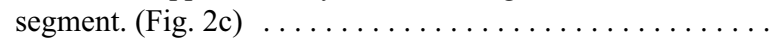
............. M. (Micromeloe) uralensis Pallas, 1777 - Head, $1^{\text {st }}$ thoracic segment and $2^{\text {nd }}-9^{\text {th }}$ abdominal segments brown; meso-, metathorax and $1^{\text {st }}$ abdominal segment yellow. Terminal seta approximately 3.6 times longer than $3^{\text {rd }}$ antennal segment. This segment approximately 2.7 times longer than $2^{\text {nd }}$ antennal segment

.... M. M. (Micromeloe) decorus Brandt \& Erichson, 1832

11 Body light, yellow (except brown lateral parts of head) or

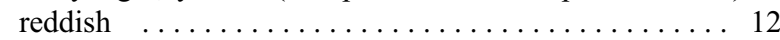

- Body dark, brown to black ................. 14

12 Body reddish, body length $1.15-1.25 \mathrm{~mm} \ldots \ldots \ldots \ldots$ ....... . M. (Eurymeloe) mediterraneus G. Müller, 1925 Body yellow, except brown lateral parts of head. Body shorter ......................... 13

13 Entire head, pronotum and sometimes also meso- and metanotum light brownish. Parietal region of head dark coloured. Head approximately 1.5 times longer than wide. Setae on abdominal segments II-VII approximately one half to three quarters the length of tergite and approximately three quarters that of entire sternite. Caudal setae as long as tergite VI-IX together

M. (Eurymeloe) rugosus Marsham, 1802
- Head, pro-, meso- and metanotum yellow except brownish, circular areas around stemmata. Head approximately 1.4 times wider than long (Fig. 3c). Maximum length of setae on abdominal segments II-VII one quarter that of tergite (except PR7) and one half that of sternite. Caudal setae as long as tergite VII-IX together (Fig. 3a) . . .......... .. M. (Eurymeloe) scabriusculus Brandt \& Erichson, 1832

14 Body brownish dorsally, yellowish ventrally. Head approximately 1.1 times wider than long; head narrowly rounded. Prothorax approximately 1.5 times wider than long, and approximately twice longer than mesothorax $\ldots \ldots \ldots$. ............ M.(Eurymeloe) brevicollis Panzer, 1793 - Body completely dark brown or black. Head approximately 1.2 times longer than wide. Head obtusedly rounded. Prothorax approximately twice wider than long, and nearly as long as mesothorax ... M. (Coelomeloe) tuccius Rossi, 1792

ACKNOWLEDGEMENTS. In particular we would like to thank J. Lange from the Westphalian Wilhelms University of Münster, Germany, for his great support to prepare the photos obtained by scanning electron microscop. Special thanks also to J.D. Pinto (University of California at Riverside, USA) and M.A. Bologna (University Roma Tre, Italy) for their revision of the manuscript and their important hints and suggestions. Apart from J.D. Pinto, D. Stein (Kassel, Germany) reviewed the English.

\section{REFERENCES}

Assmuss E.P. 1865: Familie Vesicantia (Mulsant.) Blasenziehkäfer. In: Die Parasiten der Honigbiene und die durch dieselben bedingten Krankheiten dieser Insekten. Nach eigenen Erfahrungen und neuesten Standpunkten der Wissenschaft. Schotte, Berlin, pp. 11-24.

BLAIR K.G. 1942: The first-stage larva of Meloe violaceus Maesh. (Col., Meloidae). Entomol. Month. Mag. 78: 112-116.

Bologna M.A. 1988: Note su Eurymeloe e revisione delle specie euromediterranee del gruppo "rugosus". Frag. Entomol. 20(2): 233-301.

Bologna M.A. 1991: Coleoptera Meloidae. Fauna d'Italia $X X V$. Edizioni Calderini, Bologna, $554 \mathrm{pp}$.

Bologna M.A. 1994a: I Meloidae della Grecia (Coleoptera). Frag. Entomol. (Suppl.) 25: 1-119.

Bologna M.A. 1994b: Meloidae from Canary and Macaronesian islands (Coleoptera). Misc. Zool. 16: 73-80.

Bologna M.A. \& Di Giulio A. 2002: Review of the southern African genus Prolytta Kaszab, with a description of the firstinstar larva, and bionomic and taxonomic remarks (Coleoptera, Meloidae). Bull Ann. Soc. R. Belge Entomol. 125: 67-75.

Bologna M.A. \& Pinto J.D. 1995: The triungulin of two palaearctic Meloe subgenera: Lasiomeloe Reitter and Micromeloe Reitter (Coleoptera, Meloidae), with bionomic and taxonomic notes. Boll. Zool. 62: 383-393.

Bologna M.A. \& Pinto J.D. 1997: Meloidae Gyllenhal, 1810 and Nemognathinae Castelnau, 1840 (Insecta, Coleoptera): proposed precedence over Horiidae Latreille, 1802. Bull. Zool. Nomenclat. 54: 226-230.

Bologna M.A. \& Pinto J.D. 2001: Phylogenetic studies of Meloidae (Coleoptera), with emphasis on the evolution of phoresy. System. Entomol. 26: 33-72.

Bologna M.A. \& Pinto J.D. 2002: The Old World genera of Meloidae (Coleoptera): a key and synopsis. J. Nat. Hist. 36: 2013-2102.

\footnotetext{
* According to van Emden (1958) there are two distinctly different triungulins of Meloe violaceus (a light and a dark form), which might represent different species distinguishable only by the triungulins (see also Blair, 1942). Solving this problem will be the task of further investigations.
} 
Bologna M.A., Aloisi G. \& Marangoni C. 1989: Nuove osservazioni su Eurymeloe Reitter e descrizione di larve di I stadio (Coleoptera, Meloidae). Bull. Ann. Soc. R. Belge Entomol. 125: $67-75$.

Cros A. 1914: Le Meloe autumnalis Ol. var. cribripennis Dej. (= punctipennis Heyd.), moeurs - évolution. Bull. Soc. Hist Nat. Afr. Nord 6(2): 42-52, 103-112, 155-160, 202-205.

Cros A. 1919: Notes sur les larves primaires des Meloidae avec indication de larves nouvelles. Ann. Soc. Entomol. Fr. 88 261-279

Cros A. 1921: Notes sur les larves primaires des Meloidae avec indication de larves nouvelles (2. Ser.). Ann. Soc. Entomol. Fr. 90: 133-155.

Cros A. 1929a: Notes sur les larves primaires des Meloidae (3. Ser.). Ann. Soc. Entomol. Fr. 98: 193-222.

Cros A. 1929b: Observations nouvelles sur les Méloés: Le Meloe tuccius. Ann. Sci. Nat. (Zool.) 10: 137-191.

Cros A. 1930: Description de la larve d'un coléoptère inconnu de la famille des Meloidae. Bull. Soc. Sc. Nat. Maroc 10 57-61.

Cros A. 1934: Sur les Pediculus melittae Kirby. Ann. Sc. Nat. Zool. Biol. Anim. 17: 59-66.

Cros A. 1935: Description d'une larve primaire de Meloe de provenance Marocaine et d'espèce inconnue. Bull. Soc. Sc. Nat. Maroc 15: 51-57.

Cros A. 1941: Le Meloe variegatus. Sa présence dans le Nord de l'Afrique. Sa biologie. Eos 17: 313-334.

Danielyan S.G. \& Nabaldyan K.M. 1971: The causal agents of meloids in bees. Veterinariya 8: 64-65 (in Russian).

Di Giulio A., Bologna M.A. \& Pinto J.D. 2002: Larval morphology of the Meloe subgenus Mesomeloe: inferences on its phylogenetic position and a first instar larval key to the Meloe subgenera (Coleoptera: Meloidae). Ital. J. Zool. 69: 339-344.

HACHFELD G. 1928: Über die Biologie und Metamorphose einer bei Trachusa serratulae Pz. schmarotzenden Meloide. Z. Wiss. Insektenbiol. 23: 177-190.

HACHFELD G. 1931: Über die Primärlarve der Meloe brevicollis Panz. und über die bis jetzt bekannten Primärlarven deutscher Meloiden. Z. Wiss. Insektenbiol. 26: 42-47.

KASZAB Z. 1981: Faunistische und taxonomische Studien über Meloiden (Coleoptera). Ann. Hist.-Nat. Mus. Natn. Hung. 73: 159-185.
LücKmanN J. 1999: 110. Familie Meloidae. In Klausnitzer B. (ed.): Die Larven der Käfer Mitteleuropas. Vol. 5. Polyphaga, Part 4. G. Fischer, Jena, Stuttgart, Lübeck, Ulm, pp. 287-301.

LÜCKMANN J. 2001: Zur Natur- und Kulturgeschichte der Meloiden (Coleoptera). Ver. Westd. Entomol. Tag 2000: 159-166.

LÜCKMANN J. (in press): The courtship behaviour of Meloe decorus Brand \& Erichson, 1832 and Sitaris muralis Foerster, 1771 (Coleoptera: Meloidae). Coleop. Bull.

LüCKMANN J. \& Kuhlmann M. 1997: Die Triungulinen von Meloë brevicollis Panz. und Meloë rugosus Marsh. (Coleoptera: Meloidae). Entomol. Nach. Ber. 41(3): 183-189.

MacSwain J.W. 1956: A Classification of the First-InstarLarvae of the Meloidae (Coleoptera). Univ. Calif. Publ. Entomol. 12: $182 \mathrm{pp}$.

NewPort G. 1851: The natural history, anatomy and development of the oilbeetle Meloe, more especially Meloe cicatrioscus, Leach. First memoir: The natural history of Meloe. Trans. Linn. Soc. Lond. 20: 297-320.

Selander R.B. 1986: Rearing blister beetles. Insecta Mundi 1: 209-220.

SELANDER R.B. 1989: The triungulin larva of Meloe cicatricosus LEACH. Dt. Entomol. Z. (N.F.) 36: 401-407.

Selander R.B. 1990: Blister Beetles of the genus Pseudopyrota (Coleoptera: Meloidae). J. Kans. Entomol. Soc. 63(1): 46-79.

VAN EMDEN F.I. 1943: Larvae of British beetles. IV. Various small families. Entomol. Month. Mag. 79: 209-223, 259-270.

VAN EMDEN F.I. 1958: The two larval forms of Meloë violaceus Marsh., and species distinguishable only in the early stages. Proc. 10 ${ }^{\text {th }}$ Con. Entomol. Montreal 1956. Vol. 1. pp. 217-221.

Vrabec V., Viktora P. \& Hes O. 2001: New findings of Meloe decorus (Coleoptera: Meloidae) in the surroundings of Kolín and Kutná Hora and several remarks on bionomics, ecology and possibilities of protection of this species. Studie a zprávy Okresního muzea Praha-východ 14: 144-178 (in Czech, English abstr.).

WeBer L. 1893: Über die sog. Triungulinusform der Meloelarven. Ber. Ver. Naturkd. Cassel 38: 1-5.

Received May 5, 2003, revised October 17, 2003, accepted January 21, 2004 